\title{
Mitigation of Drought through Physiological Modification in Ragi under Rainfed Conditions
}

\author{
A. Anderson Amalan Kumar ${ }^{1}$, K. Krishna Surendar ${ }^{1}$ and S. Mohamed Jalaluddin ${ }^{2}$ \\ ${ }^{1}$ Crop physiology, Regional Research Station, TNAU, Paiyur, India \\ ${ }^{2}$ Regional Research Station, TNAU, Paiyur, India \\ *Corresponding author
}

\section{A B S T R A C T}

The field experiment were conducted during September 2010 to December 2010 at the Regional Research Station, Tamil Nadu Agricultural University, Paiyur to assess the effect of drought stress on growth and productivity of rainfed ragi and to identify suitable management practices through physiological modifications to mitigate the drought effect.

\section{Keywords}

Ragi, Physiological modification,

Nutrients,

Growth Hormones, Rainfed.

Article Info

Accepted:

20 January 2017

Available Online:

10 February 2017
The experiment was laid out in factorial randomized block design with three replications. The treatments comprised of four chemicals viz., TNAU Nutrient Mix (1.00\%), TNAU Nutrient Mix (1.50\%), Brassino steroids (0.1 ppm) and Cycocel (50 ppm) along with one untreated control in three ragi varieties- Paiyur 2, L-5 and GPU 28. The foliar spray method was used to spray nutrients and growth hormones at flowering stage for suitable management for stress alleviation. The effect of treatments was assessed by periodical observations on the morphological characters, dry matter partitioning, growth rates during critical stages and ultimately the yield. In this experiment, a significant difference was observed in plant height, number of tillers per plant, number of ear heads per plant and dry matter production per plant. Except Cycocel $(50 \mathrm{ppm})$, all the other treatments showed positive influence in increasing the morphology, growth and development of the plant. Among the treatments, TNAU nutrient mix (1.5\%) with a mean yield of $2078 \mathrm{~kg} / \mathrm{ha}$ and a yield advantage of $22.1 \%$ over control was found to be best treatment in alleviating the drought stress. Application of TNAU nutrient mix (1.0\%) and Brassino steroids (0.1 ppm) were also found to be effective as these treatments were on par with the best treatment. The overall performance of Paiyur 2 was the best among the three varieties tested and confirms its suitability for all seasons.

\section{Introduction}

Millets are major food and feed sources in the developing world especially in the semiarid tropical regions of Africa and Asia. The most widely cultivated millets are pearl millet (Pennisetum glaucum (L.) R. Br.), finger millet (Eleusine coracana (L.) Gaertn), foxtail millet (Setaria italica (L.) P. Beauvois), Japanese barnyard millet (Echinochloa esculneta (A. Braun) H. Scholz), Indian
Barnyard millet (Echinochloa frumetacea Link), kodo millet (Paspalum scrobiculatum L.), little millet (Panicum sumatrense Roth.ex.Roem. and Schult.), proso millet (Panicum miliaceum L.), tef (Eragrostis tef (Zucc.) Trotter) and fonio or acha (Digitaria exilis (Kippist) Stapf and D. iburua Stapf). Millets are resilient to extreme environmental conditions especially to inadequate moisture 
and are rich in nutrients. Millets are also considered to be a healthy food, mainly due to the lack of gluten (a substance that causes coeliac disease) in their grain. Despite these agronomic, nutritional and health-related benefits, millets produce very low yield compared to major cereals such as wheat and rice. This extremely low productivity is related to the challenging environment in which they are extensively cultivated and to the little research investment in these crops (Martel, 1997).

However, the contribution of Indiato global millet production is significant. In 2013, India produced over $30 \%$ of the global millet yield from only $25 \%$ of the global millet area, mainly due to improved productivity. In the same year, while the mean seed yield of millet in India was $1.2 \mathrm{t}$ ha-1, it was only $0.8 \mathrm{t} \mathrm{ha}^{-1}$ for other countries. Millets are resilient to the extreme climatic and soil conditions prevalent in the semi-arid Regions Similar to maize and sorghum, finger millets possess a C4 photosynthesis system (Brutnell, 2010); hence, they prevent photorespiration and, as a consequence, efficiently utilize the scarce moisture present in the semi-arid regions. Since C4 plants are able to close their stomata for long periods, they can significantly reduce moisture loss through the leaves. In addition to its tolerance to drought, tef is tolerant to waterlogging especially in poorly drained soils where other crops such as maize and wheat could not survive.

Biotic stresses such as insect pests and diseases are a cause for substantial yield losses to diverse types of millets. However, abiotic stresses are the biggest contributor to losses every year. Although, in general, millets perform better than cereals such as wheat and rice in semi-arid environments, these challenging climatic and soil conditions are by no means an optimum environment for millet cultivation. In semi-arid and arid environments where finger millet and other millets are the dominant crops, drought or inadequate moisture is the major abiotic stress affecting productivity (Warner, 1988). With a view to elicit information on these aspects, field and laboratory investigations were undertaken to meet out the objectives of to assess the effect of drought on growth and productivity and to identify the suitable management practices through physiological modification to mitigate the drought stress.

\section{Materials and Methods}

The field experiment was conducted at the Regional Research Station, Tamil Nadu Agricultural University, Paiyur. The experiment was laid out in factorial randomized block design with three replications (Table 1). The treatments comprised of four chemicals viz., TNAU Nutrient Mix (1.00\%), TNAU Nutrient Mix (1.50 \%), Brassinosteroids (0.1 ppm) and Cycocel (50 ppm) along with one untreated control in three ragi varieties- Paiyur 2, L-5 and GPU 28 with the spacing of $30 \mathrm{~cm} \times 10 \mathrm{~cm}$ (Table 2). The Foliar spray using Knapsack sprayer fitted with hollow cone nozzle @ 500 lit $\mathrm{ha}^{-1}$ of spray volume during flower initiation stage.

The morphological and yield observations were recorded at 70 DAS and at Harvest stages viz., plant height, Root length, Number of tillers, Total dry matter production, Number of ear heads and grain yield. The physiological growth attributes character of Crop Growth Rate and Relative Growth Rate was recorded between 70 DAS and Harvest stage.

\section{Results and Discussion}

Morphological observations were recorded on the day of imposition of treatments (70 DAS) and at harvest. The observations recorded are given in tables 3-7. 
Significant difference was observed in plant height between the varieties at both the stages of observation (70 DAS and harvest). The variety GPU 28 recorded the maximum plant height of $111.9 \mathrm{~cm}$ at 70 DAS and $118.5 \mathrm{~cm}$ at harvest respectively and was significantly superior to Paiyur 2 and L 5. Though numerical differences were observed due to treatment effect, it was not significant at both the stages of observation. There was no significant difference between varieties, treatments and the interaction for root length (70 DAS) and number of ear heads per hill (70 DAS and at harvest).

There was significant difference for total dry matter production among varieties at both the stages of observation. The variety GPU 28 recorded the maximum dry weight of 36.30 $\mathrm{g} /$ plant at 70 DAS and $90.59 \mathrm{~g} / \mathrm{plant}$ at harvest and was significantly superior to Paiyur 2 at both the stages of observation and on par with L 5 at harvest. Though there was no significant difference among the treatments at 70 DAS, the effect of treatment was significant at harvest. The treatment, TNAU nutrient mix $(1.5 \%)$ recorded the highest mean total dry matter of $91.21 \mathrm{~g} / \mathrm{plant}$ and was on par with TNAU nutrient mix (1.0\%) and Brassino steroids (0.1ppm). Cao and Chen (1995), who reported that, BR-induced expansion is accompanied by proton extrusion and hyperpolarization of cell membranes and these effects have also been observed in the asymmetric expansion of the joint pulvini of rice laminae and it was accelerate the growth cycle in rice plant. Cycocel (50 ppm) recorded the least dry weight of $74.15 \mathrm{~g} / \mathrm{plant}$ and was on par with the control (79.18 g/plant).

Table.1 Crop wise details of the field experiment conducted

\begin{tabular}{|l|c|}
\hline \multicolumn{1}{|c|}{ Details } & Crop I \\
\hline Plot size & $3.0 \mathrm{~m} \times 3.0 \mathrm{~m}$ \\
Date of sowing & 13.09 .2010 \\
Date of application of treatments & 22.11 .2010 \\
Date of harvest & 24.12 .2010 \\
Rainfall (mm) & 450.6 \\
No. of rainy days & 31 \\
\hline
\end{tabular}

Table.2 Nutrient composition of TNAU nutrient mixture $\left(\mathrm{mg} \mathrm{L}^{-1}\right)$

\begin{tabular}{|l|c|c|}
\hline Chemical & TNAU Nutrient Mix (1.0 \%) & TNAU Nutrient Mix (1.5 \%) \\
\hline Ferrous sulphate & 3000 & 4500 \\
Zinc sulphate & 3000 & 4500 \\
Potassium nitrate & 2000 & 3000 \\
Magnesium sulphate & 750 & 1125 \\
Borax & 750 & 1125 \\
Citric acid & 250 & 375 \\
Salicylic acid & 150 & 225 \\
Giberellic acid & 100 & 150 \\
\hline Total & $\mathbf{1 0 0 0 0}$ & $\mathbf{1 5 0 0 0}$ \\
\hline
\end{tabular}


Table.3 Physiological modification on plant height $(\mathrm{cm})$ and root length $(\mathrm{cm})$ in Ragi under rainfed conditions at 70 DAS

\begin{tabular}{|l|c|c|c|c|c|c|c|c|}
\hline \multirow{2}{*}{\multicolumn{1}{|c|}{ Treatments }} & \multicolumn{4}{|c|}{ Plant height $(\mathrm{cm})$} & \multicolumn{3}{c|}{ Root length $(\mathrm{cm})$} \\
\cline { 2 - 9 } & Paiyur 2 & L 5 & GPU 28 & Mean & Paiyur 2 & L 5 & GPU 28 & Mean \\
\hline TNAU nut. mix (1.0\%) & 82.3 & 89.0 & 107.7 & $\mathbf{9 3 . 0}$ & 21.0 & 23.0 & 19.3 & $\mathbf{2 1 . 1}$ \\
TNAU nut. mix (1.5\%) & 92.7 & 97.3 & 105.3 & $\mathbf{9 8 . 4}$ & 22.0 & 20.3 & 22.3 & $\mathbf{2 1 . 5}$ \\
Brassinosteroids(0.1 ppm) & 87.0 & 91.7 & 116.3 & $\mathbf{9 8 . 3}$ & 24.3 & 22.7 & 22.0 & $\mathbf{2 3 . 0}$ \\
Cycocel (50 ppm) & 84.0 & 94.3 & 117.7 & $\mathbf{9 8 . 7}$ & 23.7 & 20.7 & 19.3 & $\mathbf{2 1 . 2}$ \\
Control & 91.0 & 94.0 & 112.3 & $\mathbf{9 9 . 1}$ & 22.7 & 22.0 & 22.0 & $\mathbf{2 2 . 2}$ \\
Mean & $\mathbf{8 7 . 4}$ & $\mathbf{9 3 . 3}$ & $\mathbf{1 1 1 . 9}$ & & $\mathbf{2 2 . 7}$ & $\mathbf{2 1 . 7}$ & $\mathbf{2 1 . 0}$ & \\
\hline & V & T & V X T & & V & T & V x T & \\
\hline SED & 2.96 & 3.82 & 13.57 & & 1.54 & 1.99 & 3.45 & \\
CD(0.05) & 6.07 & NS & NS & & NS & NS & NS & \\
\hline
\end{tabular}

Table.4 Physiological modification on number of tillers hill ${ }^{-1}$ and total dry matter $g$ plant ${ }^{-1}$ in ragi under rainfed conditions at $70 \mathrm{DAS}$

\begin{tabular}{|c|c|c|c|c|c|c|c|c|}
\hline \multirow[b]{2}{*}{ Treatments } & \multicolumn{4}{|c|}{ No. of tillers per hill } & \multicolumn{4}{|c|}{ Total dry matter $(\mathrm{g})$ per plant } \\
\hline & Paiyur 2 & L 5 & GPU 28 & Mean & Paiyur 2 & L 5 & GPU 28 & Mean \\
\hline TNAU nut. mix $(1.0 \%)$ & 2.23 & 2.27 & 2.33 & 2.27 & 18.12 & 22.72 & 35.93 & 25.59 \\
\hline TNAU nut. mix (1.5\%) & 2.23 & 2.13 & 2.47 & 2.27 & 19.41 & 22.32 & 38.49 & 26.74 \\
\hline Brassinosteroids $(0.1 \mathrm{ppm})$ & 2.10 & 2.23 & 2.67 & 2.33 & 17.37 & 21.58 & 35.87 & 24.94 \\
\hline Cycocel (50 ppm) & 2.43 & 2.13 & 2.50 & 2.35 & 17.88 & 24.67 & 35.49 & 26.01 \\
\hline Control & 2.33 & 2.27 & 2.20 & 2.26 & 19.67 & 23.69 & 35.70 & 26.35 \\
\hline Mean & 2.26 & 2.20 & 2.43 & & 18.49 & 23.00 & 36.30 & \\
\hline & $\mathrm{V}$ & $\mathrm{T}$ & $\mathrm{V} \times \mathrm{T}$ & & $\mathrm{V}$ & $\mathrm{T}$ & $\mathrm{V} \times \mathrm{T}$ & \\
\hline SED & 0.18 & 0.23 & 0.40 & & 2.05 & 2.65 & 4.60 & \\
\hline $\mathrm{CD}(0.05)$ & NS & NS & NS & & 4.21 & NS & NS & \\
\hline
\end{tabular}

Table.5 Physiological modification on plant height $(\mathrm{cm})$ and root length $(\mathrm{cm})$ in ragi under rainfed conditions at harvest stage

\begin{tabular}{|l|c|c|c|c|c|c|c|c|}
\hline \multirow{2}{*}{\multicolumn{1}{|c|}{ Treatments }} & \multicolumn{4}{|c|}{ Plant height $(\mathrm{cm})$} & \multicolumn{5}{c|}{ No. of ear heads per hill } \\
\cline { 2 - 9 } & Paiyur 2 & L 5 & GPU 28 & Mean & Paiyur 2 & L 5 & GPU 28 & Mean \\
\hline TNAU nut. mix (1.0\%) & 96.7 & 97.3 & 121.3 & $\mathbf{1 0 5 . 1}$ & 9.3 & 5.7 & 7.0 & $\mathbf{7 . 3}$ \\
TNAU nut. mix (1.5\%) & 97.7 & 101.3 & 121.7 & $\mathbf{1 0 6 . 9}$ & 7.3 & 7.3 & 7.7 & $\mathbf{7 . 4}$ \\
Brassinosteroids(0.1 ppm) & 99.0 & 98.7 & 123.3 & $\mathbf{1 0 7 . 0}$ & 8.3 & 5.3 & 7.3 & $\mathbf{7 . 0}$ \\
Cycocel (50 ppm) & 91.3 & 97.7 & 112.7 & $\mathbf{1 0 0 . 6}$ & 5.0 & 4.3 & 6.3 & $\mathbf{5 . 2}$ \\
Control & 93.7 & 99.3 & 113.3 & $\mathbf{1 0 2 . 1}$ & 6.0 & 4.7 & 7.3 & $\mathbf{6 . 0}$ \\
Mean & $\mathbf{9 5 . 8}$ & $\mathbf{9 8 . 9}$ & $\mathbf{1 1 8 . 5}$ & & $\mathbf{7 . 2}$ & $\mathbf{5 . 5}$ & $\mathbf{7 . 1}$ & \\
\hline & $\mathrm{V}$ & $\mathrm{T}$ & $\mathrm{V} \times \mathrm{T}$ & & $\mathrm{V}$ & $\mathrm{T}$ & $\mathrm{V} \times \mathrm{T}$ & \\
\hline & 2.38 & 3.07 & 5.32 & & 1.09 & 1.41 & 2.45 & \\
\hline SED & 4.87 & NS & NS & & NS & NS & NS & \\
\hline
\end{tabular}


Table.6 Physiological modification on total dry matter g plant ${ }^{-1}$ and grain yield $\left(\mathrm{kg} \mathrm{ha}^{-1}\right)$ in Ragi under rainfed conditions at harvest stage

\begin{tabular}{|l|c|c|c|c|c|c|c|c|}
\hline \multirow{2}{*}{\multicolumn{1}{|c|}{ Treatments }} & \multicolumn{3}{|c|}{ Total dry matter (g/plant) } & \multicolumn{4}{c|}{ Grain Yield (kg/ ha) } \\
\cline { 2 - 9 } & Paiyur 2 & L 5 & GPU 28 & Mean & Paiyur 2 & L 5 & GPU 28 & Mean \\
\hline TNAU nut. mix (1.0\%) & 76.86 & 96.43 & 91.23 & $\mathbf{8 8 . 1 1}$ & 2502 & 2502 & 2520 & $\mathbf{2 5 0 8}$ \\
TNAU nut. mix (1.5\%) & 78.56 & 96.55 & 98.51 & $\mathbf{9 1 . 2 1}$ & 2442 & 2669 & 2873 & $\mathbf{2 6 6 1}$ \\
Brassino steroids(0.1 ppm) & 72.93 & 94.64 & 89.55 & $\mathbf{8 5 . 7 4}$ & 2273 & 2487 & 2527 & $\mathbf{2 4 2 9}$ \\
Cycocel (50 ppm) & 58.07 & 78.07 & 86.33 & $\mathbf{7 4 . 1 5}$ & 1856 & 2331 & 2207 & $\mathbf{2 1 3 1}$ \\
Control & 68.40 & 81.81 & 87.33 & $\mathbf{7 9 . 1 8}$ & 2036 & 2211 & 2456 & $\mathbf{2 2 3 4}$ \\
Mean & $\mathbf{7 0 . 9 3}$ & $\mathbf{8 9 . 5 0}$ & $\mathbf{9 0 . 5 9}$ & & $\mathbf{2 2 2 2}$ & $\mathbf{2 4 4 0}$ & $\mathbf{2 5 1 6}$ & \\
\hline & V & T & V x T & & V & T & V x T & \\
\hline & 4.36 & 5.64 & 9.76 & & 151 & 195 & 339 & \\
CD(0.05) & 8.93 & 11.55 & NS & & NS & 401 & NS & \\
\hline
\end{tabular}

Table.7 Physiological modification on crop growth rate and relative growth rate in ragi under rainfed conditions at harvest stage

\begin{tabular}{|l|c|c|c|c|c|c|c|c|}
\hline \multirow{2}{*}{ Treatments } & \multicolumn{4}{|c|}{ Crop Growth Rate $\left(\mathrm{g} / \mathrm{m}^{2} /\right.$ day) } & \multicolumn{3}{c|}{ Relative Growth Rate (mg/g/day) } \\
\cline { 2 - 9 } & Paiyur 2 & L 5 & GPU 28 & Mean & Paiyur 2 & L 5 & GPU 28 & Mean \\
\hline TNAU nut. mix (1.0\%) & 59.33 & 74.45 & 55.86 & $\mathbf{6 3 . 2 2}$ & 19.02 & 19.02 & 12.26 & $\mathbf{1 6 . 7 7}$ \\
TNAU nut. mix (1.5\%) & 59.75 & 74.98 & 60.63 & $\mathbf{6 5 . 1 2}$ & 18.40 & 19.27 & 12.37 & $\mathbf{1 6 . 8 8}$ \\
Brassino steroids(0.1 ppm) & 56.12 & 72.79 & 54.22 & $\mathbf{6 1 . 0 4}$ & 18.88 & 18.86 & 12.04 & $\mathbf{1 6 . 5 9}$ \\
Cycocel (50 ppm) & 40.60 & 53.94 & 51.35 & $\mathbf{4 8 . 6 3}$ & 15.50 & 15.16 & 11.70 & $\mathbf{1 4 . 1 2}$ \\
Control & 49.22 & 58.71 & 52.15 & $\mathbf{5 3 . 3 6}$ & 16.40 & 16.31 & 11.77 & $\mathbf{1 4 . 8 3}$ \\
Mean & $\mathbf{5 3 . 0 0}$ & $\mathbf{6 6 . 9 7}$ & $\mathbf{5 4 . 8 4}$ & & $\mathbf{1 7 . 6 4}$ & $\mathbf{1 7 . 7 3}$ & $\mathbf{1 2 . 0 3}$ & \\
\hline & $\mathrm{V}$ & $\mathrm{T}$ & V x T & & V & T & V x T & \\
\hline & 1.60 & 2.06 & 3.57 & & 0.24 & 0.31 & 0.55 & \\
\hline CD $(0.05)$ & 3.27 & 4.22 & 7.31 & & 0.50 & 0.65 & 1.12 & \\
\hline
\end{tabular}

Significant difference was recorded between treatments for grain yield. The maximum mean grain yield of $2661 \mathrm{~kg} / \mathrm{ha}$ was recorded in TNAU nutrient mix $(1.5 \%)$ treatment followed by TNAU nutrient mix $(1.0 \%)$ with $2508 \mathrm{~kg} / \mathrm{ha}$ and Brassino steroids (0.1ppm) with $2429 \mathrm{~kg} / \mathrm{ha}$ and these treatments were on par with each other. Cycocel (50 ppm) recorded the lowest yield $2131 \mathrm{~kg} / \mathrm{ha}$ and was on par with the control (2234 kg/ha). Among the varieties, GPU 28 recorded the mean grain yield of $2516 \mathrm{~kg} / \mathrm{ha}$ followed by L 5 with $2440 \mathrm{~kg} / \mathrm{ha}$ and Paiyur 2 with $2222 \mathrm{~kg} / \mathrm{ha}$. All the three varieties were on par with each other. The interaction effect for variety and treatment was insignificant.

Growth parameters viz., Crop Growth Rate (CGR) and Relative Growth Rate (RGR) from flowering to maturity were calculated based on the dry weight recorded at both the stages. Significant difference was observed for Crop Growth Rate and Relative Growth Rate for varieties and treatments. Among the three varieties, L- 5 recorded the maximum CGR of $66.97 \mathrm{~g} / \mathrm{m}^{2} /$ day and RGR of $17.73 \mathrm{mg} / \mathrm{g} /$ day was significantly superior to Paiyur 2 and GPU 28 for CGR and was on par with Paiyur 
2 for RGR. TNAU nutrient mix (1.5\%) recorded the maximum CGR (65.12 $\mathrm{g} / \mathrm{m}^{2} /$ day $)$ and RGR (16.88 $\mathrm{mg} / \mathrm{g} /$ day $)$ and was on par with TNAU nutrient mix (1.0\%) and Brassino steroids (0.1 ppm).

\section{References}

Brutnell, T.P., et al., Setaria viridis: a model for C4 photosynthesis. The Plant cell, 2010. 22(8): p. 2537-2544.

Cao HP, Chen SK. 1995. Brassino steroid induced rice lamina joint inclination and its relation to indole-3-acetic acid and ethylene. Plant Growth Regul. 16:18996

Martel, E., Genome size variation and basic chromosome number in pearl millet and fourteen related Pennisetum species. Journal of Heredity, 1997. 88(2): p. 139-143.

Warner, D.A. and G.E. Edwards, $C-4$ Photosynthesis and Leaf Anatomy in Diploid and Autotetraploid PennisetumAmericanum (Pearl-Millet). Plant Science, 1988. 56(1): p. 85-92.

\section{How to cite this article:}

Anderson Amalan Kumar, A., K. Krishna Surendar and Mohamed Jalaluddin, S. 2017. Mitigation of Drought through Physiological Modification in Ragi under Rainfed Conditions. Int.J.Curr.Microbiol.App.Sci. 6(2): 1864-1869. doi: http://dx.doi.org/10.20546/ijcmas.2017.602.210 